nent in the denervated group than in the intact group.

In the hypoxic state, we concluded that the neurogenic factors exert a suppressive action upon autoregulation of the cerebral circulation.

In the hypercapneic state, autoregulation of the cerebral circulation is observed only in the intact group. Therefore, we consider that autoregulatory mechanism of the cerebral circulation exerts through media of neurogenic factors in the hypercapneic state.

\title{
50. The Effect of Hyperventilation on Cerebral Circulation (II) Changes in CSFP, EEG, Blood Gases after Hyperventilation
}

\author{
Taira Watanabe, Hiroshi Takeshita and Akira Inamoto \\ Department of Anesthesiology, Kyoto University School of Medicine
}

In 12 subjects with normal CSFP under halothane-nitrous oxide-oxygen anesthesia, the effects of hyperventilation on CSFP, blood gases and $\mathrm{pH}$, and electroencephalogram were studied before, during and after hyperventilation.

Within 5 minutes following institution of hyperventilation, there was a rapid fall in CSFP associated with a decrease of mean arterial $\mathrm{Pco}_{2}$ from $38 \mathrm{mmHg}$ to $16 \mathrm{mmHg}$ with resultant increase of mean $\mathrm{pH}$ from 7.406 to 7.668. At the same time mean jugular $\mathrm{Po}_{2}$ decreased from $57 \mathrm{mmHg}$ to $24 \mathrm{mmHg}$.

Occurrence and duration of EEG slowing appeared within 10 minutes after the onset of hyperventilation were variable and not consistent. During entire period of hyperventilation EEG recording showed no significant change. The CSFP gradually returned and raised over the initial value at approximately 90 minutes of hyperventilation. Initial decrease in CSFP was due to well known fact of cerebral vasoconstriction produced by a decrease in arterial $\mathrm{Pco}_{2}$. Gradual return of CSFP was considered to be a redistribution between cerebral blood volume and cerebrospinal fluid volume.

As arterial $\mathrm{PCO}_{2}$ returned to near normal level after the end of hyperventilation, there was rebound phenomenon indicating rapid increase in cerebral blood flow without compensatory decrease in cerebrospinal fluid volume. EEG slowing during rebound phenomenon consisted of high voltage, 1 to $3 \mathrm{cps}$ activity. Posthyperventilation EEG slowing was reliable and consistent. The immediate cause of EEG slowing during and after hyperventilation remained obscure. Post-hyperventilation EEG slowing appeared when arterial $\mathrm{Pco}_{2}$ was normal, jugular $\mathrm{Po}_{2}$ was increased to $60 \mathrm{mmHg}$ and $\mathrm{pH}$ was significantly changed from 7.654 to 7.329 After hyperventilation arterial $\mathrm{pH}$ and base excess showed the occurrence of metabolic acidosis. Evidences observed after hyperventilation in this study sug. 
gested that severe and prolonged hyperventilation was harmful from aspect of changes in CSFP, EEG and acid-base balance.

\title{
51. Cerebral Blood Flow in Ruptured Aneurysm
}

\author{
Hajime NagaI, Kazuhiko OKamura, Inazo Toda, Ryohei HayaKawa, \\ Yoshiaki Suzuki, Tatsuya KobaYashi and Shin Hoshikawa \\ 2nd Department of Surgery, Nagoya University School of Medicine
}

Regional cerebral blood flow was measured by $\mathrm{Kr} 85$ clearance method in 6 patients with ruptured intracranial aneurysm which was proved by angiogram.

Four of them had aneurysm in the anterior communicating artery, one in the anterior cerebral artery and the last one in the internal carotid artery. In 5 of 6 patients, locarized or diffuse vasospasm was observed obviously in angiogram.

Measurements of cerebral blood flow were performed one day to 3 weeks after the onset of the stroke. All of them remained unconscious at the time of procedure;

Table.

\begin{tabular}{|c|c|c|c|c|c|c|c|c|}
\hline $\begin{array}{c}\text { No. } \\
\text { of } \\
\text { case }\end{array}$ & age & $\operatorname{sex}$ & $\begin{array}{l}\text { days after } \\
\text { the onset }\end{array}$ & $\begin{array}{l}\text { clinical } \\
\text { manifestation }\end{array}$ & location & \multicolumn{3}{|c|}{$\underset{\text { R-side }}{\mathrm{CBFr}}$ L-side } \\
\hline 1 & 55 & $\mathrm{~F}$ & 10 & $\begin{array}{l}\text { coma } \\
\text { 1-hemiparesis }\end{array}$ & ant. comm. a. & $\begin{array}{l}\text { front. } \\
\text { temp. }\end{array}$ & $\begin{array}{l}25.0 \\
24 \cdot 3\end{array}$ & $\begin{array}{l}23.6 \\
21.2\end{array}$ \\
\hline 2 & 29 & $\mathbf{M}$ & 13 & $\begin{array}{l}\text { lethalgic } \\
\text { tetraparesis }\end{array}$ & ant. comm. a. & $\begin{array}{l}\text { front. } \\
\text { temp. }\end{array}$ & $\begin{array}{l}28.1 \\
36.8\end{array}$ & $\begin{array}{l}33.2 \\
34.8\end{array}$ \\
\hline 3 & 50 & $M$ & 1 & $\begin{array}{l}\text { comatose } \\
\text { bl-oculomotor palsy }\end{array}$ & ant. comm. a. & temp. & 33.0 & 38.5 \\
\hline 4 & 59 & F & 2 & $\begin{array}{l}\text { lethalgic } \\
\text { r-hemiparesis }\end{array}$ & 1-ant. cereb. a. & temp. & 32.6 & 39.2 \\
\hline 5 & 60 & M & 4 & $\begin{array}{l}\text { drowsy } \\
\text { 1-hemiparesis }\end{array}$ & ant. comm. a. & temp. & 37.0 & 41.0 \\
\hline 6 & 37 & $\mathrm{~F}$ & 17 & $\begin{array}{l}\text { lethalgic, optic choke } \\
\text { 1-hemiparesis }\end{array}$ & r-int. carot. a. & $\begin{array}{l}\text { front. } \\
\text { temp. }\end{array}$ & $\begin{array}{l}34.5 \\
35.5\end{array}$ & $\begin{array}{l}44.0 \\
40.0\end{array}$ \\
\hline
\end{tabular}

2 were comatose and 4 lethalgic.

$\mathrm{Kr} 85$ dissolved in saline was injected into the internal carotid artery and the clearance of the isotope was recorded from the frontal and temporal region simultaneously.

The cerebral blood flow was calculated from the clearance curve by compartment analysis.

The results were summarized in the table.

All the patients had a reduced cerebral blood flow; in 4 cases of anterior communicating aneurysm it decreased in the both hemisphere, while in one of internal 